\title{
Expression Malondialdehyde (MDA) of Brain after Injury with the Extract of Kencur (Kaempferia Galanga L) (Experimental Study Wistar Rats)
}

\author{
Mahendra Budi Sagita \\ Department of Neurosurgery, Faculty of Medicine Universitas Airlangga - Dr. Soetomo Academic General \\ Hospital, Surabaya, Indonesia \\ Email: hendra.nsua@gmail.com
}

\author{
Agus Turchan \\ Department of Neurosurgery, Faculty of Medicine Universitas Airlangga - Dr. Soetomo Academic General \\ Hospital, Surabaya, Indonesia \\ Corresponding author email: agusturchan@yahoo.com

\section{Budi Utomo} \\ Department of Public Health Science and Preventive Medicine, Faculty of Medicine Universitas Airlangga - Dr. \\ Soetomo Academic General Hospital, Surabaya, Indonesia \\ Email: budiutom@gmail.com \\ Asra Al Fauzi \\ Department of Neurosurgery, Faculty of Medicine Universitas Airlangga - Dr. Soetomo Academic General \\ Hospital, Surabaya, Indonesia \\ Email: asraalfauzi@gmail.com

\section{Dyah Fauziah} \\ Department of Pathology Anatomy, Faculty of Medicine Universitas Airlangga - Dr. Soetomo Academic General \\ Hospital, Surabaya, Indonesia \\ Email:dyahf73@gmail.com
}

\begin{abstract}
Neurological damage in brain injury occurs due to secondary brain injury. Kencur extract has antioxidant potential with total phenolic and flavonoid content including luteolin apigenin and is expected to reduce MDA expression to prevent secondary injury. This study is an experimental laboratory. The treatment of all samples was carried out simultaneously using a post-test-only control group design. Based on the ANOVA test, the significance value of the Kencur extract treatment group was $0.000(p<0.05)$ indicating that there was a difference in MDA expression in brain-injured rats without kencur extract with brain-injured rats and given kencur extract. In the 24-hour and 48-hour time groups, a significance value of 0.488 ( $p>0.05)$ showed no significant difference in MDA expression. Then the Kencur extract treatment group with a time group of $0.117(p>0.05)$ showed no significant difference in MDA expression. There was a significant difference in the expression of MDA in braininjured rats without kencur extract with brain-injured rats and given kencur extract. There were no significant differences in the MDA expression in the 24-hour and 48-hour time groups and the Kencur extract treatment group and the 24-hour and 48-hour time groups.
\end{abstract}

Keywords---expression malondialdehyde (MDA), brain after injury, extract of kencur, experimental study Wistar rats, Kaempferia Galanga L. 
Introduction

Brain injury is still a problem faced by many neurosurgeons and in Indonesia, it is still the main cause of disability, death and requires high costs to treat. Today, along with advances in technology and development as well as activities and the increasing number of human populations, the frequency of brain injury is not decreasing but tends to increase (Roozenbeek et al., 2013). This is due to the increasing number of motorized vehicles, especially twowheelers, as well as the undisciplined behavior of motorized vehicle drivers on the streets.

One of the factors that influence the pathophysiology of TBI is a secondary brain injury. Secondary brain injury includes oxidative stress which can cause extensive brain tissue damage (Cornelius et al., 2013). TBI results in increased ROS and causes lipid peroxidation. Malondialdehyde (MDA) is the end product formed during lipid peroxidation caused by the degradation of cell membrane phospholipids (Lorente et al., 2015). MDA expression can also be used as a TBI biomarker and high expression is also found in patients, especially in patients who are unable to survive as a result of TBI. The lipid peroxidation process is divided into 3 phases. The first phase is the initiation phase where free radicals interact with polyionic fatty acids to form lipid radicals. Next is the propagation phase which is characterized by the reaction of peroxyl radicals with unsaturated fatty acids to form hydroxy peroxides and new lipid radicals. Then the last is the termination phase when 2 radicals combine to form non-radical compounds or are terminated by antioxidants (Hall et al., 2010). The increase in MDA expression was caused by hyper oxidative conditions, namely an imbalance between antioxidants and pro-oxidants. So antioxidants are needed to overcome this imbalance (Rodrigo et al., 2013). Kencur extract can react with free radicals to produce a more stable product and stop the radical chain reaction. The ABTS cation radical reacts with hydrogen donating antioxidants and therefore the solution is colorless. This assay is commonly used to measure the radical activity of hydrogen donors and chain-breaking antioxidants in plant extracts (Pisoschi \& Negulescu, 2011). According to Umar et al. (2012), Kencur extract (Kaempferia galangal L.) has anti-inflammatory, analgesic, nematicidal, mosquito repellent, larvicidal, vasorelaxant, sedative, antineoplastic, antimicrobial, antioxidant, and antiallergic effects.

The above study shows that Kencur extract has the potential as an alternative to antioxidant therapy in reducing oxidant reactions in secondary brain injury (Suh et al., 2000; Başkaya et al., 1997). Therefore, the researchers wanted to analyze the expression of malondialdehyde brain (MDA) after injury by giving Kencur extract (Kaempferia galanga $L$ ).

\section{Methods}

This research is a laboratory experiment with simple random sampling. Therefore, experimental animals, experimental sites, and other research materials can be said to be homogeneous. All samples were treated simultaneously and after a long treatment, observations were made using the Posttest Only Control Group Design (Notoatmodjo, 2003). The research design used a posttest-only control group. This design, it allows researchers to measure the effect of treatment (intervention) on the experimental group by comparing the experimental group with the control group. Experimental animals used in this study were male Wistar rats, aged $2.5-3$ months, bodyweight 280-320 grams, healthy, and obtained from the Bogor Agricultural Institute. The selection of rats as experimental animals was based on the consideration that Wistar rats are genetically similar to humans and can adapt to the laboratory environment (Weber et al., 2019) Sample allocation (grouping) used simple random by first numbering each rat.

The research was carried out for 5 (five) months, covering the stages of preparation of materials and tools, treatment, examination, and preparation of reports. The treatment of experimental animals was carried out for 1-2 days, then the brain tissue preparations were examined on day 3 in the form of the number of cells expressing MDA from injured ipsilateral brain tissue in male Wistar rats (Bhattacharya \& Muruganandam, 2003; Fogacci et al., 2016), with a 400x light microscope, positive cells were counted in 5 fields of view (high power field/HPF) in each sample (Ali et al., 2005; Liu et al., 2016).

The treatment of research subjects in the form of traumatic brain injury / TBI was given to 3 experimental groups (groups B, C, and D) one treatment, and after that, the research subjects of groups C and D were given Kencur extract ( $600 \mathrm{mg} / \mathrm{kgBW}$ and $1200 \mathrm{mg} / \mathrm{kgBW})$. The experimental animals were healthy male rats, looked active, aged 2.5-3 months, bodyweight 280-320 grams as many as 36 tails (Yao et al., 2018; Jagadish et al., 2016). All these mice were marked with a number on their fur, which would be used in the process of the randomization sample. The research data that showed the effect of Kencur extract (Kaempferia galanga $L$.) were then tested for significance with a significance level of 5\% $(p=0.05)$ and analyzed with SPSS version 20. 


\section{Results and Discussion}

ANOVA tests were used to determine whether there were differences in MDA expression in rats were treated with injury without giving Kencur extract, injured with $600 \mathrm{mg}$ Kencur extract, and injured with $1200 \mathrm{mg}$ Kencur extract.

Table 1

Table test results Two-Way ANOVA

\begin{tabular}{lc}
\hline \multicolumn{1}{c}{ Two-Way ANOVA Test } & $p$ \\
\hline Treatment & 0,000 \\
Time & 0,488 \\
Treatment*Time & 0,117 \\
\hline
\end{tabular}

In table 1 , the results of the ANOVA test show that the significant value in the treatment group is $0.000(p<0.05)$, which means that there is a difference in MDA expression. in injured rats without giving Kencur extract with injured rats and given Kencur extract. In the 24-hour and 48-hour time groups, a significance value of 0.488 ( $p>0.05$ ) showed that there was no significant difference in MDA expression. Then in the treatment group, Kencur extract with a time group of 24 hours and 48 hours obtained a significance value of $0.117(p>0.05)$ indicating no significant difference in MDA expression.

Table 2

Table of test results the Post Hoc Tukey

\begin{tabular}{llcc}
\hline & Treatment Group & $\mathrm{n}$ & $p$ \\
\hline Negative Control & Positive Control & 5 & 0,000 \\
& Treatment + Kencur Extract $600 \mathrm{mgs}$ & 5 & 0,727 \\
& Treatment + Kencur Extract $1200 \mathrm{mgs}$ & 5 & 0,408 \\
Positive Control & Treatment + Kencur Extract $600 \mathrm{mgs}$ & 5 & 0,000 \\
& Treatment + Kencur Extract $1200 \mathrm{mgs}$ & 5 & 0,000 \\
Treatment + Kencur Extract 600 mgs & Treatment + Kencur Extract $1200 \mathrm{mgs}$ & 5 & 0,951 \\
\hline
\end{tabular}

Results of the Post Hoc Tukey test are a follow-up test from the test Two-Way ANOVA, wherein the treatment group the significance value is $0.000(p<0.05)$, which means that there is a significant difference in the group. The test was Post Hoc Tukey's used to test the differences between the 2 groups with a significance value of $p<0.05$. Based on the table of test results Post Hoc Tukey:

- The negative control group against the positive control group obtained a significance value of $0.000(p<0.05)$, which means that there is a significant difference in the 2 groups;

- The positive control group to the treatment group with the administration of kencur extract at doses of $600 \mathrm{mg}$ and $1200 \mathrm{mg}$ had a significance value of $p<0.05$ so that it could be concluded that there was a significant difference;

- The negative control group to the treatment group with the administration of $600 \mathrm{mg}$ or $1200 \mathrm{mg}$ of Kencur extract had a significance value of $p>0.05$ so it can be concluded that there was no significant difference;

- The treatment group with $600 \mathrm{mg}$ Kencur extract against the treatment group with $1200 \mathrm{mg}$ Kencur extract had a significance value of $p>0.05$, which means that there was no significant difference between the two groups. 




Figure 1. Positive control (Injury (+) \& kencur (-)), Rat neuron cell stained brown positive for MDA (arrow) in 400x magnification

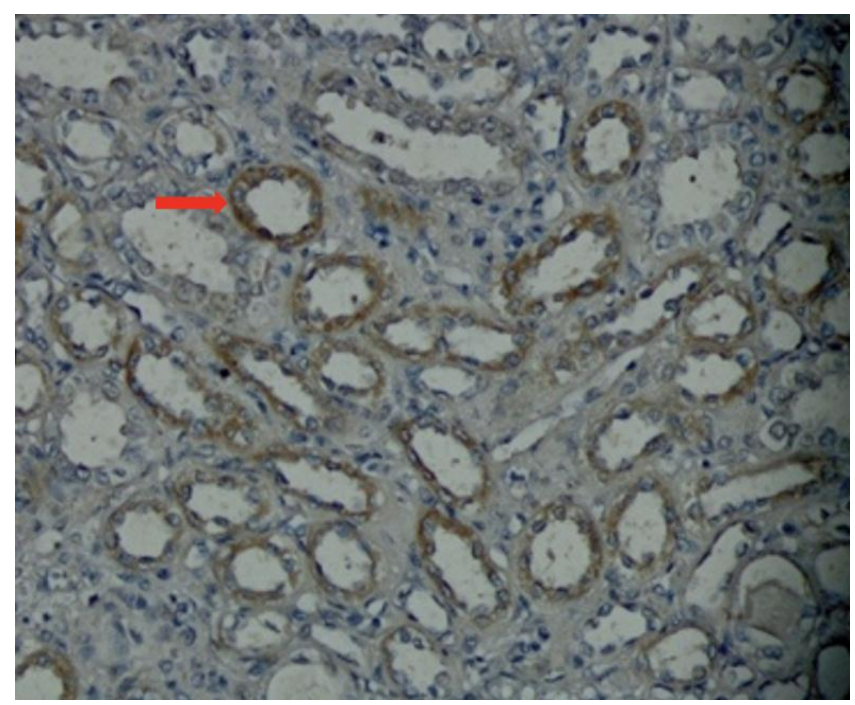

Figure 2. Negative control (Injury (-) \& kencur (-)), Rat neuron cell stained brown positive for MDA (arrow) in 400x magnification 


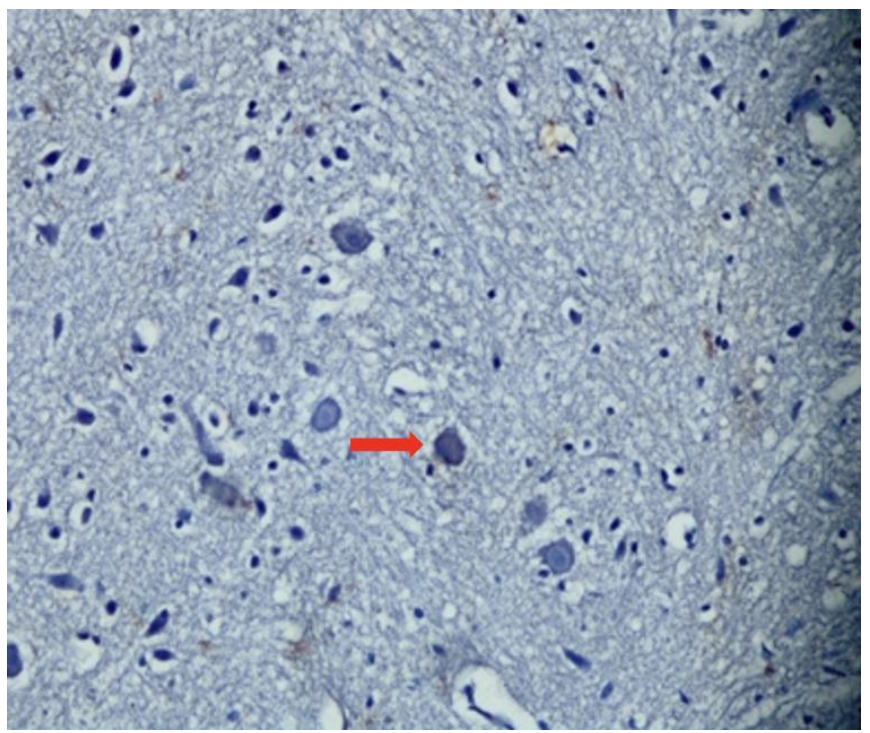

Figure 3. Brain Injury + Kencur Extract $600 \mathrm{mg}$, rat neuron cell stained brown positive for MDA (arrow) in 400x magnification

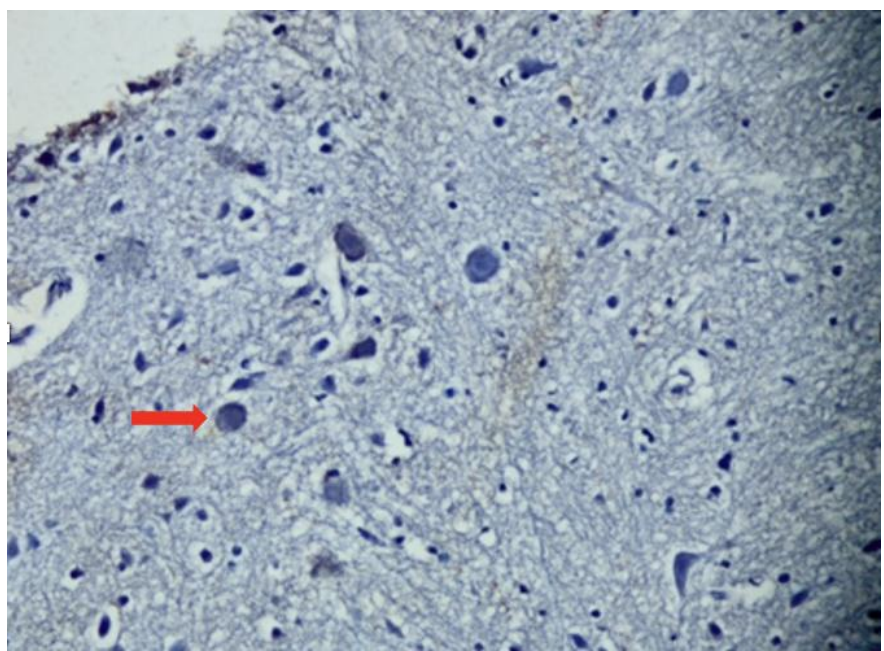

Figure 4. Brain Injury + Kencur Extract $1200 \mathrm{mg}$, rat neuron cell stained brown positive for MDA (arrow) in 400x magnification

The figures of the 4 research groups above using IHC PA staining and observed with a serial magnification microscope 100x, 200x, and 400x in each group shows MDA expression in neurons where cells are stained brown (Figure 4). Positive expression of molecules with primary antibodies will appear brown under a 400x light microscope. The counted brain cells were located in the subgranular zone (SGZ) of the hippocampal gyrus dentate, positive cells were counted in 5 fields of view (HPF) in each sample (Gobe et al., 1999).

The picture of the positive control study group (brain injury (+) and Kencur extract (-)) showed MDA expression in the microscope field of view with an average cell count of $0-5$ positive cells per 100 neuron cells. The picture of the negative control study group (brain injury (-) and Kencur extract (-)) showed MDA expression painted brown with an average cell count of 10-20 positive cells per 100 neuron cells in the microscope field of view. The picture of the brain injury research group with a dose of $600 \mathrm{mg}$ Kencur extract showed brown-colored MDA expression with an average count of 0-4 positive cells per 100 neuron cells in the microscope field of view. The picture of the brain injury research group with a dose of $1200 \mathrm{mg}$ Kencur extract showed brown-colored MDA expression with an average cell count of 0-3 positive cells per 100 neuron cells in the microscope field of view (Wido et al., 2022). 
The results of this study are in line with the research of Mustafa et al which showed that Kencur extract also has antioxidant potential and can reduce MDA expression. The content of total phenolic and flavonoid which includes luteolin and apigenin can act as antioxidant properties (Mustafa et al., 2010). The antioxidant effect of Kencur extract as measured by DPPH assay in this study showed that the antioxidants present in Kencur extract were thought to act as hydrogen donors and were responsible for the reduction of DPPH (Kurniawan et al., 2022). DPPH activity of Kencur extract showed a strong and positive correlation with its total phenolic $(\mathrm{R} 2=0.932, p<0.05)$ and flavonoid content $(\mathrm{R} 2=0.955, p<0.05)$ indicating a possible reduction in DPPH supported by high total phenolic content. and flavonoids (Islam et al., 2013). Kencur extract can react with free radicals to produce a more stable product, stopping the radical chain reaction (Kanjanapothi et al., 2004; Othman et al., 2006). The ABTS cation radical reacts with hydrogen donating antioxidants and therefore the solution is colorless (Pisoschi \& Negulescu, 2011).

The results of this study are also in line with research by Aroonrerk \& Kamkaen (2009), which showed Kaemferia galanga $L$ had inhibitory effects on IL-6 and anti-PGE2 and inhibited COX-2. Research Noro et al. (1983), stated Kaemferia galangal $L$ as an MAO (inhibitor Monoamine Oxidase).

Research by Vittalrao et al. (2011), stated that Kaempferia galangal L in two doses, $600 \mathrm{mg} / \mathrm{kg}$ and $1200 \mathrm{mg} / \mathrm{kg}$, contained anti-inflammatory properties. Two doses of extract Kaempferia galangal $L$ were significantly different in containing analgesic activity when compared to the control group. The antioxidant content of Kencur from the rhizome is Total Phenolic Content (TPC) $57 \mathrm{mg}$ gallic acid equivalent (GAE)/100 g. The antioxidant content in Kencur rhizome is $17 \mathrm{mg}$ ascorbic acid (AA)/100 $\mathrm{g}$ (Chan et al., 2009).

MDA expression can also be used as a TBI biomarker and high expression is also found in patients, especially in patients who are unable to survive as a result of TBI (Lorente et al., 2015). Research on rats exposed to streptozotocin (STZ) showed that a mixture of bee pollen, Kencur rhizome, turmeric, and areca nut, could reduce MDA expression (Sutaryono et al., 2016). The stability of phenoxyl radicals is reported to reduce the rate of propagation reaction in the lipid autoxidation process which will reduce the final product, namely MDA. In addition, the in vitro test of Kencur extract which measures the level of inhibition of lipid peroxidation showed that Kencur extract can inhibit lipid peroxidation so that it will reduce the final product, namely MDA (Mohanty et al., 2008).

\section{Conclusion}

Research on expression malondialdehyde brain(MDA)after injury by giving Kencur extract (Kaempferia galanga L) to experimental animals Wistar rats at FK UNAIR/Dr. Soetomo Hospital Surabaya concluded that there were differences in MDA expression in injured rats without Kencur extract and injured rats and given Kencur extract. There was no significant difference in MDA expression in the MDA expression in the 24-hour and 48-hour time groups and the Kencur extract treatment group and the 24-hour and 48-hour time groups.

\section{Acknowledgments}

The author expresses his deep gratitude for all support and feedback. We also extend our gratitude to the Neurosurgery Department and the Medical Faculty of Airlangga universities. Without the help and support of all parties, this would not be possible.

\section{References}

Ali, M. B., Hahn, E. J., \& Paek, K. Y. (2005). Effects of light intensities on antioxidant enzymes and malondialdehyde content during short-term acclimatization on micropropagated Phalaenopsis plantlet. Environmental and Experimental Botany, 54(2), 109-120. https://doi.org/10.1016/j.envexpbot.2004.06.005

Aroonrerk, N., \& Kamkaen, N. (2009). Anti-inflammatory activity of Quercus infectoria, Glycyrrhiza uralensis, Kaempferia galanga and Coptis chinensis, the main components of Thai herbal remedies for aphthous ulcer. Journal of Health Research, 23(1), 17-22.

Başkaya, M. K., Rao, A. M., Doğan, A., Donaldson, D., \& Dempsey, R. J. (1997). The biphasic opening of the blood-brain barrier in the cortex and hippocampus after traumatic brain injury in rats. Neuroscience letters, 226(1), 33-36. https://doi.org/10.1016/S0304-3940(97)00239-5

Bhattacharya, S. K., \& Muruganandam, A. V. (2003). Adaptogenic activity of Withania somnifera: an experimental study using a rat model of chronic stress. Pharmacology Biochemistry and Behavior, 75(3), 547-555. https://doi.org/10.1016/S0091-3057(03)00110-2 
Chan, E. W. C., Lim, Y. Y., Ling, S. K., Tan, S. P., Lim, K. K., \& Khoo, M. G. (2009). Caffeoylquinic acids from leaves of Etlingera species (Zingiberaceae). LWT-Food Science and Technology, 42(5), 1026-1030. https://doi.org/10.1016/j.lwt.2009.01.003

Cornelius, C., Crupi, R., Calabrese, V., Graziano, A., Milone, P., Pennisi, G., ... \& Cuzzocrea, S. (2013). Traumatic brain injury: oxidative stress and neuroprotection. Antioxidants \& redox signaling, 19(8), 836-853.

Fogacci, M. F., da Silva Barbirato, D., Amaral, C. D. S. F., da Silva, P. G., de Oliveira Coelho, M., Bertozi, G., ... \& Leão, A. T. T. (2016). No association between periodontitis, preterm birth, or intrauterine growth restriction: experimental study in Wistar rats. American Journal of obstetrics and Gynecology, 214(6), 749-e1. https://doi.org/10.1016/j.ajog.2015.12.008

Gobé, G., Willgoss, D., Hogg, N., Schoch, E., \& Endre, Z. (1999). Cell survival or death in renal tubular epithelium after ischemia-reperfusion injury. Kidney international, 56(4), 1299-1304. https://doi.org/10.1046/j.15231755.1999.00701.x

Hall, E. D., Vaishnav, R. A., \& Mustafa, A. G. (2010). Antioxidant therapies for traumatic brain injury. Neurotherapeutics, 7(1), 51-61.

Islam, M. R., Beg, M. D., \& Gupta, A. (2013). Characterization of laccase-treated kenaf fibre reinforced recycled polypropylene composites. BioResources, 8(3), 3753-3770.

Jagadish, P. C., Latha, K. P., Mudgal, J., \& Nampurath, G. K. (2016). Extraction, characterization and evaluation of Kaempferia galanga L.(Zingiberaceae) rhizome extracts against acute and chronic inflammation in rats. Journal of Ethnopharmacology, 194, 434-439. https://doi.org/10.1016/j.jep.2016.10.010

Kanjanapothi, D., Panthong, A., Lertprasertsuke, N., Taesotikul, T., Rujjanawate, C., Kaewpinit, D., ... \& Pitasawat, B. (2004). Toxicity of crude rhizome extract of Kaempferia galanga L.(Proh Hom). Journal of Ethnopharmacology, 90(2-3), 359-365. https://doi.org/10.1016/j.jep.2003.10.020

Kurniawan, A., Turchan, A., Utomo, B., Parenrengi, M. A., \& Fauziah, D. (2022). The change of BDNF expression in traumatic brain injury after Kaempferia galanga L. administration: An experimental study. International Journal of Health \& Medical Sciences, 5(1), 101-113. https://doi.org/10.21744/ijhms.v5n1.1847

Liu, G. D., Sheng, Z., Wang, Y. F., Han, Y. L., Zhou, Y., \& Zhu, J. Q. (2016). Glutathione peroxidase 1 expression, malondialdehyde levels and histological alterations in the liver of Acrossocheilus fasciatus exposed to cadmium chloride. Gene, 578(2), 210-218. https://doi.org/10.1016/j.gene.2015.12.034

Lorente, L., Martín, M. M., Abreu-González, P., Ramos, L., Argueso, M., Cáceres, J. J., ... \& Jiménez, A. (2015). Association between serum malondialdehyde levels and mortality in patients with severe brain trauma injury. Journal of neurotrauma, 32(1), 1-6.

Mohanty, J. P., Nath, L. K., Bhuyan, N., \& Mariappan, G. (2008). Evaluation of antioxidant potential of Kaempferia rotunda Linn. Indian journal of pharmaceutical sciences, 70(3), 362.

Mustafa, R. A., Hamid, A. A., Mohamed, S., \& Bakar, F. A. (2010). Total phenolic compounds, flavonoids, and radical scavenging activity of 21 selected tropical plants. Journal of food science, 75(1), C28-C35.

Noro, T., Miyase, T., Kuroyanagi, M., Ueno, A., \& Fukushima, S. (1983). Monoamine oxidase inhibitor from the rhizomes of Kaempferia galanga L. Chemical and pharmaceutical bulletin, 31(8), 2708-2711.

Notoatmodjo, S. (2003). Prinsip-prinsip dasar ilmu kesehatan masyarakat. Jakarta: Rineka Cipta, 10.

Othman, R., Ibrahim, H., Mohd, M. A., Mustafa, M. R., \& Awang, K. (2006). Bioassay-guided isolation of a vasorelaxant active compound from Kaempferia galanga L. Phytomedicine, 13(1-2), 61-66. https://doi.org/10.1016/j.phymed.2004.07.004

Pisoschi, A. M., \& Negulescu, G. P. (2011). Methods for total antioxidant activity determination: a review. Biochem Anal Biochem, 1(1), 106.

Rodrigo, R., Fernandez-Gajardo, R., Gutierrez, R., Manuel Matamala, J., Carrasco, R., Miranda-Merchak, A., \& Feuerhake, W. (2013). Oxidative stress and pathophysiology of ischemic stroke: novel therapeutic opportunities. CNS \& Neurological Disorders-Drug Targets (Formerly Current Drug Targets-CNS \& Neurological Disorders), 12(5), 698-714.

Roozenbeek, B., Maas, A. I., \& Menon, D. K. (2013). Changing patterns in the epidemiology of traumatic brain injury. Nature Reviews Neurology, 9(4), 231-236.

Suh, S. W., Chen, J. W., Motamedi, M., Bell, B., Listiak, K., Pons, N. F., ... \& Frederickson, C. J. (2000). Evidence that synaptically-released zinc contributes to neuronal injury after traumatic brain injury. Brain research, 852(2), 268-273. https://doi.org/10.1016/S0006-8993(99)02095-8

Sutaryono, S., Andasari, S.D., Hidayati, N. (2016). Pengaruh Pemberian Campuran Bee Pollen, Rimpang Kencur, Kunyit dan Biji Pinang Terhadap Penurunan Kadar Malondialdehida (MDA) pada Tikus Wistar Pasca Paparan Streptozotocin. 
Umar, M. I., Asmawi, M. Z., Sadikun, A., Atangwho, I. J., Yam, M. F., Altaf, R., \& Ahmed, A. (2012). Bioactivityguided isolation of ethyl-p-methoxycinnamate, an anti-inflammatory constituent, from Kaempferia galanga L. extracts. Molecules, 17(7), 8720-8734.

Vittalrao, A. M., Shanbhag, T., Kumari, M., Bairy, K. L., \& Shenoy, S. (2011). Evaluation of antiinflammatory and analgesic activities of alcoholic extract of Kaempferia galanga in rats. Indian J Physiol Pharmacol, 55(1), 13-24.

Weber, B., Lackner, I., Haffner-Luntzer, M., Palmer, A., Pressmar, J., Scharffetter-Kochanek, K., ... \& Kalbitz, M. (2019). Modeling trauma in rats: similarities to humans and potential pitfalls to consider. Journal of translational medicine, 17(1), 1-19.

Wido, A., Bajamal, A. H., Apriawan, T., Parenrengi, M. A., \& Al Fauzi, A. (2022). Deep vein thrombosis prophylaxis use in traumatic brain injury patients in tropical climate. International Journal of Health \& Medical Sciences, 5(1), 67-74. https://doi.org/10.21744/ijhms.v5n1.1840

Yao, F., Huang, Y., Wang, Y., \& He, X. (2018). Anti-inflammatory diarylheptanoids and phenolics from the rhizomes of kencur (Kaempferia galanga L.). Industrial Crops and Products, 125, 454-461. https://doi.org/10.1016/j.indcrop.2018.09.026 